\title{
The Influence of Project Based Learning Model on Student Writing Skills
}

\author{
Desi Khairani $^{1(*)}$, Tressyalina ${ }^{1}$ \\ ${ }^{1}$ Masters in Indonesian Language Education, Faculty of Language and Art, Padang State University, Padang, Indonesia. \\ *Corresponding author. Email:desikhairani741@gmail.com
}

\begin{abstract}
Based on preliminary observations at SMP Negeri 1 Panyabungan, students generally had difficulty mastering writing skills. This condition is caused by the learning model used by the teacher that has not varied and is still lacking. This study aims to describe the effect of project based learning learning models on the skills of writing observational report text. This type of research is quasi-experimental research and uses Posttest-Only Control Group Design. The subjects of this study were Grade VII students of SMP Negeri 1 Panyabungan, Mandailing Natal Regency. The experimental class is treated using a project based learning model. The control class is treated using a conventional learning model. The results of this study indicate that the average value of experimental class students is 84.06 while the average value of control class students is 77.41. Based on the results of data analysis, it can be concluded that there is an effect of the project based learning model on students' writing skills. For this reason, it is recommended that Indonesian teachers use the project based learning model especially in writing skills.
\end{abstract}

\section{Keywords: project based learning, conventional, writing}

\section{INTRODUCTION}

Writing as one of the language skills in Indonesian is one of the activities that has many benefits in everyday life. Writing is an activity expressing the contents of one's thoughts, ideas, opinions, i de, and feelings ( Suhaimi 2016). Writing means pouring thoughts into writing or telling something to others through writing. Through the process of writing someone can communicate indirectly (Pranoto, 2004, p. 9).

Writing skills are closely related to literacy. Literacy is the ability to write and read (KBBI online). Writing and reading as language skills cannot be separated. Because, if someone can write well, it shows a tendency to read it too well. Conversely, someone who has good reading skills will have a tendency to become a good writer as well.

Based on the results of the study Central Connecticut State University (CCSU) in March 2016 stated that Indonesia fallow da in the order of 60 of the 61 countries surveyed. Furthermore, the results of a study for the Program for International Student Assessment (PISA) in the literacy culture of Indonesian people in 2015 ranked 62 out of 70 countries surveyed (Detiknews online, 2019). The study shows that the literacy culture of Indonesian people is still very low.

Writing is a difficult and complex skill (Heaton in Slamet, 2008, p. 141). Writing is a skill that is more difficult to master than the other three skills of listening, speaking, and reading (Nurgiyantoro, 2001). This difficulty is reasonable because it requires the attention, understanding, and seriousness of students to explore the potential that exists in him. From the perspective of students, writing is a difficult thing even considered as a scary exercise to pour thoughts on paper by paying attention to the mastery of writing rules such as spelling, citation format, and grammar (Defazio, Jones, Tennant \& Hook, 2010, p. 34 ).

Other research was also conducted by (Endah, 2012; Syahraini, 2014), not only in Indonesia but also from Iran (Mehr, Malayeri, Bayat, 2016) which suggested that writing difficulties were not only based on students' character and motivation, but also from outside students. such as finding topics, organizing sentences effectively, and writing procedures. This is what causes the ability to write among students is still low. However, writing activities carried out by everyone is a skill that can be fostered and trained (Ebo, 2005, p. 1) (Djuharie, 2005, p. 120).

One learning model that can help students develop writing skills is a project based learning model. The learning model project based learning is an instructional model that refers to the philosophical constructivism, which states that knowledge is the result of a cognitive construction through a student activity. so students can construct their own knowledge and meaningful through real experience (Liu, in Marlinda, 2012). In PjBL the students will work collaboratively by applying cooperative learning (Warsono and Hariyanto, 2012). 
The learning model project based learning is a learning model that uses as a learning project or activity to achieve competence attitudes, knowledge, and skills (Kemendikbud, in Priyatni, 2014). Abidin (2014, p.172) explains that the steps of the project based learning model consist of 8 , as follows. First, the preproject: done by teachers outside of class hours that is designing project descriptions, preparing media and various learning resources. Second, identify the problem: students make observations on the object and then formulate the problem in the form of questions. Third, make a project design and implementation schedule. Fourth, carry out research to collect data. Fifth, compile the initial product draft as a plan and the results of research conducted. Sixth, formulate project results. Seventh, present the results of the project. Eighth, evaluating and completing project results.

The project based learning model in its application has several advantages compared to other learning models. The strengths of the project based learning model according to (Kemendikbud, 2013) are as follows. 1) increase student learning motivation, encourage their ability to do important work and they need to be appreciated; 2) make students become more active and successfully solve complex problems; 3) provide students with learning experiences and practices in organizing projects and making time allocations and other resources such as equipment for completing assignments; and 4) making the learning atmosphere enjoyable so students and teachers can enjoy the learning process.

Some of the previous studies conducted by Ferdi et al. (2017). The results showed that by applying the project based learning model can improve students' accuracy and creative arts. Then the research conducted by Maya Nurfitriyanti (2016). The results of his study indicate that there is an influence on the application of the project based learning model to the ability to solve mathematical problems. Further research conducted by Andita Put r i , et al (2018) suggested that the application of learning models project based learning can improve learning outcomes and creativity of students.

Based on several previous studies, it shows that research on the effect of project based learning learning models on the skills of writing observational report texts has never been done. Thus, the formulation of the problem of this research is whether the project based learning model affects the writing skills of the report text of junior high school students' observations.

\section{METHOD}

This type of research is quantitative research. Quantitative research is research in which the research data are in the form of numbers and analysis using statistics starting from data collection, data interpretation, and finally results (Arikunto, 2002, p. 19); (Sugiyono, 2012, p. 7). The method used is the quasiexperimental method (quasy experiment). The research design used was posttest-only control group design. This design consists of two groups and given different treatments, namely the experimental class and the control class.

This research was conducted at SMP Negeri 1 Panyabungan in the odd semester of the 2019/2020 school year. The population of this study was all students of class VII. The population is tested for normality and homogeneity. The results show that the population is normal and homogeneous. The technique used in determining the sample is purposive sampling technique. Sampling is based on consideration of the objectives to be achieved (Sugiyono, 2012, p. 95). The results of the sample selection are class VII 1 as an experimental class and class VII 2 as a control class. The experimental class is a group that is given treatment that is learned by using a project based learning model. While the control class is not treated with the project based learning model, but with learning that is usually done by the teacher, namely the lecture method.

The data instrument in this study was a performance test used as a post-test. This test is in the form of an essay consisting of one item and serves to find out the students' skills in writing observation report text. Data collection in this study uses assessment techniques on student test results based on assessment indicators. Indicators to be assessed in writing the text of the observation report are the structure of the general definition, the structure of the part description, the structure of the description of the benefits, the accuracy of the sentence structure, and the spelling of the Indonesian language (EBI). There are two data analysis in this study namely. 1) A prerequisite test consisting of a normality test and a homogeneity test. 2) hypothesis testing using the two sample paired $t$ test (independent sample $t$ test).

\section{RESULTS AND DISCUSSION}

The data in this study is the score of the results of the writing skills of the text of the students' observations obtained from the performance tests. This result score is obtained after learning in the experimental class using the project based learning model and in the control class using the conventional learning model. Overall it can be seen that the average experimental class taught using the project based learning model is higher than the average control class taught using the conventional learning model of the five indicators. The average frequency of the results of the test of writing the text of the observation report per indicator of the experimental class and the control class can be seen in the following table and figure.

Table 1. Skill Test Results of Observation Report Text Writing Results Experiment Class and Control Class per Indicator

\begin{tabular}{|l|l|l|l|}
\hline No. & Assessed Indicator & Experiment & Control \\
\hline 1 & General Definition & 64.51 & 41.37 \\
\hline 2 & Section Description & 41.93 & 24,13 \\
\hline 3 & Description of Benefits & 80.64 & 79.31 \\
\hline 4 & $\begin{array}{l}\text { The accuracy of } \\
\text { sentence structure }\end{array}$ & 68.06 & 27.58 \\
\hline 5 & $\begin{array}{l}\text { Indonesian Spelling } \\
\text { (EBI) }\end{array}$ & 32.25 & 31.03 \\
\hline
\end{tabular}


Based on these data graphs obtained differences in aspects of the ability to write text reports on observations between the experimental class and the control class, can be seen in Figure 1.

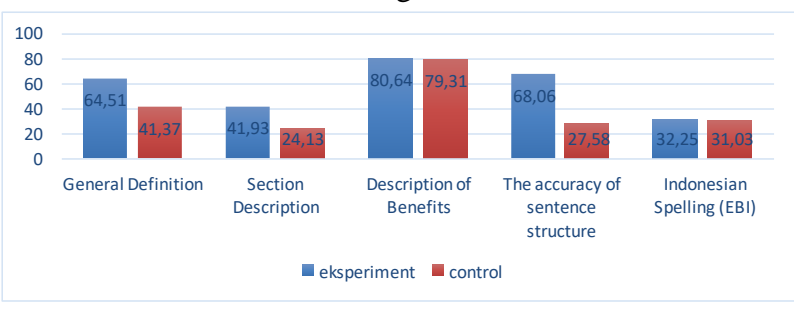

Figure 1. Comparison of Results Test Writing Skills Text of Observation Reports on Experiment Class and Control Class by Indicator

In this study three test were conducted, namely a descriptive data test, a prerequisite test for data analysis, and a data analysis test. Data descriptive tests conducted included calculating mean, median, mode, variance, and standard deviation. To test prarequirement that the data analysis test for normality and homogeneity. Data analysis test is done by $\mathrm{t}$ test.

\section{Data Descriptive Test}

The results of descriptive data calculations calculated using Microsoft Excel 2010 are as follows.

Table 1. Data Descriptive Test

\begin{tabular}{|l|l|l|}
\hline & Experimentation Class & Control class \\
\hline The mean & 84.06 & 77.41 \\
\hline Median & 86 & 80 \\
\hline Mode & 94 & 67 \\
\hline Variance & 62.06 & 121.96 \\
\hline $\begin{array}{l}\text { Standard } \\
\text { Deviation }\end{array}$ & 7.87 & 11.04 \\
\hline
\end{tabular}

Based on the above table, it is known that the results of the calculation of the average value of experimental class students in writing the text of the observation report are higher than the average value of the control class students. This can be seen in the calculation of the description of the data which shows that the average value of the experimental class students was 84.06 while the average value of the control class students was 77.41. The median or middle value in the experimental class is 86 while the median in the control class is 80 . The mode or value that most often appears in the experimental class is 94 while the mode in the control class is 67 . The variance in the experimental class is 6.06 while the variance in the class the control is 121.96. Furthermore, the standard deviation in the experimental class was 7.87 while the standard deviation in the control class was 11.04.

\section{Test Prerequisites for Data Analysis}

Normality test

The results of normality test calculations are calculated using Microsoft Excel 2010 as follows.
Table 2. Normality Test

\begin{tabular}{|l|l|l|l|l|}
\hline & $\mathbf{N}$ & $\begin{array}{l}\text { L } \\
\text { count }\end{array}$ & Ltable & Information \\
\hline Experiment & 31 & 0.1329 & 0.1593 & $\begin{array}{l}\text { Normal } \\
\text { distribution }\end{array}$ \\
\hline Control & 29 & 0.1367 & 0.161 & $\begin{array}{l}\text { Normal } \\
\text { distribution }\end{array}$ \\
\hline
\end{tabular}

Based on the above table, it is known that the data in the experimental class and the control weld are normally distributed. This can be seen in the calculation of the normality test with the results which state that the Lhitung in the experimental class and the control class is smaller than the Ltable with $\alpha 0.05$. Lhitung <Ltable, it is stated that the experimental class and control class data are normally distributed.

Homogeneity Test

Homogeneity test calculation results are calculated using Microsoft Ex 2010 as follows.

Table 3. Homogeneity Test

\begin{tabular}{|l|l|l|l|l|l|}
\hline Sample & N & S. & $\begin{array}{l}\text { Fcou } \\
\text { nt }\end{array}$ & $\begin{array}{l}\text { Ftabl } \\
\text { e }\end{array}$ & Information \\
\hline $\begin{array}{l}\text { Experime } \\
\text { nt }\end{array}$ & 31 & 7.87 & 1.40 & 1.84 & $\begin{array}{l}\text { Homogeneo } \\
\text { us }\end{array}$ \\
\hline Control & 29 & 11.04 & & & \\
\hline
\end{tabular}

The above table shows that the greatest variance results in a control class is 11.04 , while the smallest variance in the experimental class of 7.87, then $\mathrm{f} h$ generated 1.40 and $\mathrm{ft}$ obtained 1.84 . So, it can be concluded that the results of the text writing skills test report on the observation results of the experimental class and the control class have homogeneous variances because $\mathrm{F}$ arithmetic $<\mathrm{F}$ table or $1.40<1.84$.

\section{Data Analysis Test}

The results of the calculation of the hypothesis test $(t)$ were calculated using Microsoft Excel 2010 as follows. Table 4. Test Data Analysis

\begin{tabular}{|l|l|l|l|}
\hline & Experiment & Control & Information \\
\hline $\mathrm{N}$ & 31 & 29 & \\
\hline $\mathrm{X}$ & 84.06 & 77.41 & \multirow{3}{*}{ H0 is rejected } \\
\cline { 1 - 2 } $\mathrm{S}$. & 7.87 & 11.04 & \\
\hline $\mathrm{t}_{\text {count }}$ & 2,916 & & \\
\hline $\mathrm{t}_{\text {table }}$ & 1,671 & \\
\hline
\end{tabular}

Based on the above table using the $t$ test obtained $\mathrm{t}$ count $=2.916$ at $\alpha=0.05$ level obtained $\mathrm{t}$ table 1.671 with $\mathrm{dk}=58$. It can be concluded that the hypothesis is accepted because $t$ arithmetic $>t$ table or 2.916>1.671. It means that the average score of the test skills in writing the report text of the results of observations of the experimental class students who were taught using the project based learning model was higher than the average test scores of the writing skills of the report on the results of the observation of the control class students who were taught using conventional learning models. 


\section{CONCLUSION}

Based on the results of the study, it is known that the use of project based learning learning models can influence the ability of students in learning the skills of writing observational report text. This can be seen in the results of the calculation of the average value of the experimental class students in writing the report text of the observation results higher than the average value of the control class students ie the average value of the experimental class students is 84.06 while the average value of the class students the control is 77.41 .

Based on the results and discussion that has been described, it is recommended for Indonesian language teachers to apply the project based learning model especially in writing skills.

\section{REFERENCES}

[1] Abidin, Y. (2014). Learning System Design in the Context of Curriculum 2013 Bandung: Refika Aditama

[2] Andita, et al. (2018). Application of the project based learning model (PBJ) to improve learning outcomes and creativity of third grade students of SD Negeri Sodirejo Lor 01 Salatiga. Journal of Basic Charms. Vol 6 (1).

[3] Arikunto, S. (2002). Research Procedure: A Practical Approach. Jakarta: Rineka Cipta

[4] Defazio, J., Jones, J., Tennant, F., and Hook, SA 2010. Academic literacy: the importance and impact of writing across the curriculum - a case study. Journal of the Scholarship of Teaching and Learning. Vol 10 (2).

[5] Detiknews, (2016). Low Indonesian Literacy. (online), ( http://detiknews.com, accessed 28 October 2019)

[6] Djuharie, S. (2005). Guidance on Making Writing: Review, Book Report, Thesis, Thesis, Articles, Papers, News, Essays, etc. Bandung: Yrama Widya.

[7] Ebo, AK (2005). Writing Does Not Need Talent. Jakarta: MU: 3 Book

[8] Endah, AN (2012). Analysis of Indonesian Language Mistakes in the exposition of high school students (online) in the BASASTRA Journal of Language Research, Indonesian Literature and Teaching. Vol 1, (1), ISSN 123026405

[9] Ferdi, et al. (2017). Application of the project based learning (PJB) model to improve the accuracy and creation of art . Scientific Journal of Educational Technology, Vol 7 (2).

[10]Ministry of Education and Culture. (2013) . Indonesian Knowledge . Jakarta: Ministry of Education and Culture

[11] Mehr, MM, Malayeri, FA, Bayat, A. (2016). The effects of brainstorming as aprewriting activity on
Irani EFL learners prompted expository writing. (online) International Journal of education investigations. Vol. 3, (3), ISSN: 24103446.

[12] Nurfitriyanti, M. (2016). Project based learning model of learning ability to solve mathematical problems. Formative Journal. Vol 6 (2)

[13] Nurgiyantoro, B. (2001). Assessment in Language Learning. Yogyakarta: BPEE Yogyakarta

[14] Pranoto, N. (2004). Creative Writing: 72 Art Writing Skills. Jakarta: PT. Primadia Reader

[15] Priyatni, ET (2014). Indonesian Language Learning Design in Curriculum 2013. Jakarta: Earth Literacy

[16] Slamet, (2008). Basics of Indonesian Language Skills. Surakarta: UNS Press

[17] Sugiyono (2012). Educational Research Methods Quantitative, Qualitative, and $R \& D$ Approaches. Bandung: Alfabeta

[18] Suhaimi. (2016). Teaching writing skills on recount text based on brainstorming in the classroom. (online) Ta'dib Journal, Vol. 19, (1)

[19] Syahraini, Elvi. (2014). Improvement of news text writing skills through the contextual approach of VIII H grade students of SMP Negeri 4 Tambang Kampar Regency(online) journal Language, Literature and, Learning. Vol. 2

[20] Warsono and Hariyanto. (2012). Active Learning and Assessment Theory. Bandung: PT. Teen Rosdakarya 